http://revped.ise.ro

Print ISSN 0034-8678; Online ISSN: 2559 - 639X

\title{
OVERVIEW OF RECENT DEVELOPMENTS IN EDUCATION THROUGH ARTS AND HERITAGE IN THE ROMANIAN EDUCATION SYSTEM
}

O PRIVIRE DE ANSAMBLU ASUPRA EVOLUȚIILOR RECENTE ÎN EDUCAȚIA PRIN ARTĂ ȘI PATRIMONIU ÎN SISTEMUL EDUCAȚIONAL ROMÂNESC

\section{Angelica MIHĂILESCU}

\author{
Journal of Pedagogy, 2018 (2), 161 - 177 \\ https://doi.org/10.26755/RevPed/2018.2/161
}

The online version of this article can be found at: http://revped.ise.ro/category/2018-en/

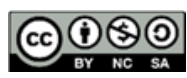

This work is licensed under the Creative Commons Attribution-NonCommercial-ShareAlike 4.0 International License. 94042, USA.

Published by:

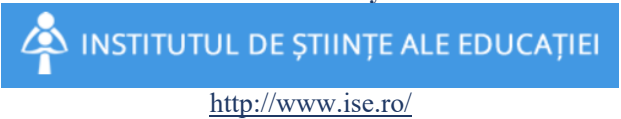

http://www.ise.ro/

Further information about Revista de Pedagogie - Journal of Pedagogy can be found at:

Editorial Policy: http://revped.ise.ro/editorial-policy/

Author Guidelines: http://revped.ise.ro/the-writer-guide-2/ 


\title{
OVERVIEW OF RECENT DEVELOPMENTS IN EDUCATION THROUGH ARTS AND HERITAGE IN THE ROMANIAN EDUCATION SYSTEM
}

\author{
Angelica Mihăilescu* \\ Institute of Educational Sciences \\ Bucharest, Romania \\ angelica.mihailescu@ise.ro
}

\begin{abstract}
This paper offers a brief analysis of the status of development of activities that aim to integrate arts, culture and heritage into K-12 education. The analysis is based on exploratory research and follows the evolution of these practices, having a 2009 Eurydice study as reference. The study was focused on beneficiaries (pupils and parents), teachers and school principals, as well as artists and cultural organisations. At national level, changes such as the introduction of a key competence based curriculum and the "Şcoala altfel" Programme ("A Different Kind of School") are positive factors in the development of educational activities dedicated to the arts, culture and heritage. What we found is that the practices and experiences produced during the analysed period reveal: an increase in the number of activities, while organizing them from the perspective of equal access to all pupils; the opening towards new artistic fields, but without significant changes in the use of new technologies. The benefits of arts, culture and heritage activities are not well exploited from the point of view of integrating them as learning opportunities in regular school activities and evaluating outcomes (often limited to evaluation of the degree of satisfaction). During the past few years schools and cultural operators have been more open to collaboration / partnership, but there is no national programme that would ensure convergent and continuous activities. We have found no significant changes in the way the issue of cultural heritage is addressed.
\end{abstract}

Keywords: Benefits for learning, education through arts and heritage, feedback quality, schools attractiveness.

* Researcher, PhD., Institute of Educational Sciences, Bucharest, Romania. 


\section{Rezumat}

Această lucrare oferă o scurtă analiză a situa iei dezvoltării activită ilor care vizează integrarea artei, culturii şi patrimoniului în sistemul de învă ământ preuniversitar. Analiza se bazează pe cercetarea exploratorie şi urmăreşte evolu ia acestor practici, având ca referin $\breve{a}$ un studiu Eurydice din 2009. Studiul a fost axat pe beneficiari (elevi şi părin i), profesori şi directori şcolari, precum şi pe artisti şi organiza ii culturale. La nivel na ional, schimbări precum introducerea unui curriculum bazat pe competen e cheie şi programul "Şcoala altfel" reprezintă factori pozitivi în dezvoltarea activită ilor educa ionale dedicate artei, culturii şi patrimoniului. Am constatat că practicile şi experien ele produse în perioada analizată relevă: o creştere a numărului de activită $i$; organizarea acestora din perspectiva accesului egal al tuturor elevilor; deschiderea către noi domenii artistice, dar fără schimbări semnificative în utilizarea noilor tehnologii. Beneficiile activită ilor dedicate artelor, culturii şi patrimoniului sunt mai pu in valorificate din punctul de vedere al integrării acestora ca oportunită i de învă are in activită ile şcolare şi al evaluării rezultatelor (adesea limitate doar la evaluarea gradului de satisfac ie). In ultimii ani, şcolile şi operatorii culturali au fost mai deschişi colaborării / parteneriatului, dar nu există un program na ional care să asigure activită $i$ convergente şi continue. Nu am identificat schimbări semnificative în ceea ce priveşte abordarea patrimoniului cultural.

Cuvinte cheie: Atractivitatea şcolii, beneficii în învă are, calitatea feedback-ului, educa ie prin artă şi patrimoniu.

\section{Introduction}

Educational activities dedicated to arts, culture and heritage play an important role in enhancing school attractiveness for pupils (Bamford \& Wimmer, 2012), and they may impact on academic performance, motivation towards learning and the classroom climate (Winner, Goldstein \& Vincent Lancrin, 2013). By observing the existing synergies between the arts, cultural heritage and education, we can see that they open significant perspectives on child social and civic development, keeping to the idea of identity and also to that of European cultural diversity (Lauret \& Marie, 2010; NACCCE, 1999). The public policy documents issued by the bodies of the European Union consider the impact which knowledge of cultural heritage may have on the development of the members of society (Council of Europe, 2005). The evolution of the Romanian educational context over the last five years reveals a tendency to 
diversify school experiences with regard to the integration of arts and cultural activities. On the other hand, in everyday practice, the approach of heritage in education seems to know no clearly shaped representation (as viewed by teachers and pupils) compared to arts and cultural activities. The expectations related to the integration of the arts, culture and heritage in pupil development throughout school education in Romania are reflected, on one hand, by initiatives in the area of non-formal learning to suggest activities that are of interest to schools and, on the other hand, by proposals of intervention mechanisms promoted by the public institutions responsible for the regulation of the formal learning sector, which allow schools to integrate all educational resources made available to them.

\section{Methodological aspects}

This study is intended to briefly explore the main aspects related to the mechanisms and practices generating educational activities dedicated to the arts, culture and heritage in Romanian school education.

The analysis was built on data coming from an exploratory research study concerning arts education in Romanian schools which involved the participation of pupils, teachers, parents, school principals and cultural operators. The research study was carried out in 2015 by a group of researchers from the Institute of Educational Sciences in Bucharest, of which I was also part (Iacob \& Mihăilescu, 2016). In this research we used questionnaires (454 pupils; 183 parents) and semi-structured interviews (34 teachers; 25 school managers; 4 persons in charge with educational and extracurricular activities; 14 artists and representatives of cultural institutions and NGOs). The field research was conducted in educational institutions (primary and lower secondary schools, high-schools) and cultural institutions and organisations.

The research findings have been compared to additional information from the evaluative research regarding the impact of educational activities included in the national programme "Şcoala altfel" (Măntălu ă \& Velea, 2013) and from the exploratory research of the mechanisms used to implement the curriculum in the classroom (Bercu, 2012). We also considered other 
information/experiences, identified through activities carried out by cultural institutions and organisations within several culture and heritage projects ${ }^{1}$.

Not last, in selecting the relevant aspects for this topic, we took into consideration the documents concerning the development of arts and cultural education in the heritage context (UNESCO 2006, 2010; Council of Europe, 2009) and the questions/findings of the Eurydice study of arts and culture at school in Europe (EACEA, 2009). While keeping in mind some of the questions structuring these documents, in the course of this article, we have aimed to analyse some aspects related to the status of the arts subjects within the current school curriculum; the provision of out of school educational activities in the area of the arts, culture and heritage available to pupils at school; the contexts in which the activities are carried out; available resources; facilitators of cultural experiences; pupils' access to these educational activities and ways to engage them; school practices of collaboration with parents or cultural institutions and organisations; identified learning benefits; the evaluation of the activity outcomes. The administrative regulations and the mechanisms in place in the Romanian school education system urge us to ask the question what capital in point of gained experience might have accrued since 2009 up to the present, with regard to the arts, culture and heritage in an educational context.

\section{New changes in curriculum and opportunities for approaching arts and heritage activities}

By comparison with the publication year of the Eurydice study of arts and culture in European schools (EACEA, 2009), the Romanian education system has known significant legislative changes generated by the new Law of National Education of 2011. In this context, the national curriculum considers the key competences (European Parliament, 2006) for the definition of the pupil development profile, brings under regulation the regime of compulsory and optional subjects and determines the forms of cross-curricular approach. New curriculum framework and subject curricula for primary education (where they are already applied) and lower secondary education have been developed so far. 
The new curriculum framework for primary education includes subjects such as "Visual Arts and Practical Skills" and "Music and Movement", in a transversal approach connecting the curricular areas of the Arts, Physical Education, Sport and Health, and Technologies. Besides the content fields dedicated to drawing, painting and music, those of photography, film, dance and eurhythmy are also explicitly present. Lower secondary education continues to provide one hour for the subjects "Arts Education" and "Music Education" in the Arts curricular area, trying to organise these content fields in a key competence perspective. The approach of the arts, culture and heritage permeates, in line with the key competences, into subjects of the curricular areas Language and Communication, Man and Society (intercultural education; history, for instance, offers an explicit place to cultural heritage), Technologies (design, activities, occupations and crafts).

In the 2011/2012 school year, the national programme "Şcoala altfel" ("A Different Kind of School") was established. The programme is dedicated to extracurricular activities, included in the school time, throughout a week. The course of the programme is presented at the beginning of the school year and it clearly indicates the typologies of educational activities, the forms of organisation and authorisation, as well as the criteria for the evaluation of outcomes. Some of the programme objectives are to foster an association environment in the local community, collaboration among teachers, parents and specialists from other institutions or organisations, in non-formal educational contexts, as well as children's learning interest. "Şcoala altfel" entered the public conscience, and the evaluative research of the first two years of application reveals that the programme has attained its objectives: $82.6 \%$ of the teachers participating in the research and $88.5 \%$ of the parents think this is a good initiative, which generates a variety of learning activities (Măntălu ă \& Velea 2013, p. 26). Among the field data provided by pupils with regard to the type of activities organised in schools, $60.30 \%$ of the answers indicate participation in cultural activities and $62 \%$ in sport activities (Măntălu ă \& Velea, 2013, p. 30). Cultural activities are more frequent in urban areas, and sport activities in rural areas. Because the programme takes place in the school time, the presence of all children is obligatory.

In the Romanian education system, schools still can develop their own optional curricula, which they consider to be of interest to each school community. 
For this purpose, they can use the time school dedicated to the school-based curriculum in the curriculum framework in effect. There is a provision of school-based curricula made available to all schools by the Ministry of National Education, which includes only an optional curriculum addressing the field of the arts, culture and heritage in primary education ("Playing the Architecture. Education for Architecture and the Built Environment"). At school level, there are more initiatives concerned with the application of optional curricula in arts and cultural education. Curricula dedicated to cultural heritage education are rare and they are usually promoted by initiatives of local cultural associations.

Every school defines its own provision of extracurricular activities annually so as to meet the quality evaluation criteria with reference to the education provided by the school. Some types of activities (i.e. competitions, contests, festivals) may be funded through the calendar of national or regional educational activities, according to the existing rules.

\section{Activities, resources and facilitators in arts and heritage activities}

The educational activities dedicated to the arts, culture and heritage take place within the school premises in almost three quarters of cases, the rest being carried out outside school. They can take place during the school hours - in the interval allotted to arts school subjects, and also punctually, at other school subjects or in the programmes carried out by the school - or after the school hours. Practices which include arts activities during classes make about a third of the experiences signalled by the participants in the research, being concentrated, in many cases, in the period of the "Şcoala altfel" Programme.

The conclusions of the study highlight some specific aspects of the implementation of this program in the Romanian schools. The provision of arts, culture and heritage activities involves, most of the time, a few experiences per semester (to the opinion of $42.8 \%$ of the parents and $56 \%$ of the pupils). As we showed in the previous chapter, the "Şcoala altfel" Programme generates a concentration, in the time assigned to it, of new 
practices and provisions. Other initiatives take place after the daily/weekly hours, and pupils' participation is discretionary. The use of the weekend indicates that there is a need to solve some organisational and resource (material, financial, human) management difficulties. Generally, the identification of time resources to carry out such activities is a challenge for teachers and for school principals, given the lack of more diverse and more flexible administrative tools which facilitate its management.

Financial support from parents is the main source of material and financial resources which are necessary to carry out activities dedicated to the arts, culture and heritage. $45.3 \%$ of the parents said that it was necessary for them to make financial contributions for the artistic and cultural activities in which their child was involved. Issues related to the identification of material and human resources are common to all situations where extracurricular activities are organised. Most teachers indicate: a lack of any tools at hand to find sponsors; a lack of qualified staff or the staff fluctuation; a lack of interest from colleagues or the community; more specific partnership mechanisms which facilitate collaboration with arts professionals and their access to schools.

Arts and cultural activities at school are mostly facilitated by teachers, to the opinion of $90.5 \%$ of the pupils and $81.7 \%$ of the parents. If teachers are more involved in the organisation of activities at primary and lower secondary level, at high-school level we can see an increase of more than $25 \%$ in pupils' involvement (which may be seen as a consequence of their increased autonomy). Approximately a quarter of the initiatives, across different segments of school education, belong to pupils and parents. In parents' view, the involvement of cultural operators from institutions or cultural organisations account for about ten percent for each of them, while the visibility of institutions which are representative to the local community is very low. As viewed by cultural operators, the facilitator role assumed by parents in the communication between the arts representatives and schools is deemed significant.

\section{Arts and cultural experiences managed by schools}

The above mentioned study highlights the specific aspects of the art and cultural activities managed at school level. More than half of the pupils 
participating in the study $(52.4 \%)$ say that the school offered them opportunities to participate in cultural events such as theatre, concerts, dance shows, movies etc. Experiences in connection with visits to museums, galleries, exhibitions are mentioned by $47.6 \%$ of the pupils. Approximately a third of the proposed experiences are dedicated to practicing the arts in the classroom or out of school (29.5\%) or to visits to/workshops in libraries or bookshops (25.3\%). Opportunities when pupils can meet artists/writers in the classroom or out of school account for $21.6 \%$ of pupils' experiences, and presentations about different artistic forms, $18.7 \%$. Out of the total respondent pupils, a percentage of $15.4 \%$ says they did not participate in any of the opportunities described above.

The artistic fields to which the pupils had access most of the times through the experiences provided by the school are music (36.6\%), literature (36.6\%) and theatre $(35 \%)$. They are followed by experiences related to drawing (28.4\%); film (25.9\%); dance (24.2\%); painting (20.6\%). The least represented ones are the experiences related to photography $(18.7 \%)$, crafts and handicrafts $(17.1 \%)$ or computer graphics $(10.7 \%)$. The fields referring to urbanism $(8.3 \%)$ or architecture $(3.8 \%)$ come below the level of ten percent.

Pupils' expectations with regard to the artistic fields to which they would like to have access through the experiences provided by schools go towards theatre, music and dance, in those forms of organisation which they encounter more often in their school life (contest, show, exhibition, club, workshop). Extending the scope of experiences towards painting, photography, drawing, computer graphics, crafts and handicrafts, visits to museums and arts galleries is of average relevance in the ensemble of pupils' opinions. These expectations may be correlated with teachers' educational goals and with the benefits which all the participants associate with the arts, culture and heritage. They acknowledge the contributions of such activities to personal development, creativity, communication and collaboration etc. Instead, they rarely speak of attitudes and behaviours concerned with cultural consumption, involvement in the conservation of heritage values, solutions to social problems.

In relation to pupils' needs in real life, teachers believe that arts and cultural activities may contribute to: developing a quality life and behavioural models; social, cultural, heritage intervention; developing observation and analysis 
skills in support of understanding of one's life. As to pupils' need of vocational guidance, the participants in the research do not seem to take into account that the approach of the arts and culture in a heritage context could be an attainable educational goal for vocational guidance and professional insertion compared to other goals (communication, personal development, creativity). Generally, finding solutions to problems which impact on society seems to concern all participants in the study less than the pursuit of social or labour market integration.

\section{Arts and cultural experiences managed by parents}

The cultural capital offered to pupils in their family is characterised by a frequency of participation in artistic events of 3-6 times a year (38.8\% of the respondent parents). Children participate in arts activities organised out of schools, as the parents say (34.9\%), whereas $65 \%$ say don't have this kind of participation. Opportunities offered by parents to their children assume their personal development through dance, visual arts, playing a musical instrument, theatre. Most of the times parents turn to private lessons for teaching of musical instruments, but they also take their children to music schools or children's clubs. For other fields - theatre, photography, creation workshops and handicrafts, parents use the most popular networks: children's clubs, cultural institutions or local associations. The activities organised by entities outside the school system are attended by more than a third of the children of the participants in the study.

\section{Consultation and collaboration in decision making}

Given the need to solve the problems related to human or material resources which are necessary to carry out activities, schools expanded their interests and experiences regarding the collaboration with their partners from museums and other cultural institutions, associations, non-governmental organisations; county cultural centres; children's clubs; other bodies involved mainly in the implementation of projects. The interviewed teachers used solutions which involved collaboration with professionals: inviting well known artists; introducing an optional subject of arts and cultural education delivered together 
with a professional (for example, the school based curriculum "Playing the Architecture. Education for Architecture and the Built Environment", for primary education); the possibility to invite some specialists at school in order to organise artistic workshops.

In their capacity of main partners of school, $44.7 \%$ of the parents say they were consulted by the school about the arts activities which are of interest to their children and that, to a large extent, their opinion was taken into account, but a similar percentage answered that they were not consulted. School's collaboration with parents supposed, as seen by the parents, providing financial support for activities (34.8\%), preparing activities $(18.6 \%)$ or carrying them out $(16.8 \% \%)$, providing feedback at the end of the activity $(24.2 \%)$.

With regard to the forms of collaboration with pupils promoted by teachers, more than half of the pupils $(64 \%)$ say that the role they played involved attending conferences or going to shows (concerts, dramas), visits to museums, etc. Active participation in the creation of artistic products (dramas, musical shows, decorative objects, etc.) was experienced by more than a third of the pupils (35\%), while only $21 \%$ of them say they had an opportunity to learn about different forms of arts (their history, basic concepts, etc.). The representatives of the artistic and cultural sector tried to come up with offers which are not limited to the artistic dimension and explore other educational, civic, intra- and interpersonal possibilities too. As we can see, pupils' involvement in arts and cultural activities implies "I attend", while, at quite a distance, there are actions such as "I actively participate in" or "I learn about". This percentage distribution, which reveals a prevalence of activities with low pupil involvement, seems to indicate a much more frequent practice in the Romanian education system.

\section{Motivation and benefits for learning}

Children's main motivation for participating in activities with an artistic dimension presumes their interest in such experiences, as about half $(50.6 \%)$ of the interviewed parents say. The values of collaboration, the enjoyment of working with their classmates are determinant for $14.6 \%$ of the parents, 
and pupils' involvement at their parents' suggestion is presumed the main motivation for $11.4 \%$ of the respondents. Almost a quarter of the parents say that the main reason for their children's participation was a teacher's requirement to do so $(23.4 \%)$.

As viewed by the pupils who were interviewed, their motivations for participating in arts and cultural activities is their interest in such experiences $(39.3 \%)$ or because this is a teacher's requirement to do so $(23.5 \%)$. These motivations are followed by a desire to try out new things (18.8\%); the enjoyment of working with their classmates $(14.4 \%)$; parents' appreciation (4.1\%). With regard to children's engagement in the activities that were carried out, more than half of the pupils say they had a role in discussing some aspects such as: the topic of the activity (65.9\%), their own impressions regarding their involvement $(65.9 \%)$; the preparation of the activity $(55.9 \%)$; ways to deliver it $(60.9 \%)$ or improving the way the activity is delivered $(49.2 \%)$.

Both pupils and parents and teachers think that these activities may have a determinant contribution to personal development and they refer to: understanding and expressing one's personal experiences (emotions and feelings); self-knowledge through discovering one's talents, intellectual development and development of one's personality; development of attitudes and convictions for life; fostering the interest in artistic events; the quality of using one's free time. Improving the learning process through activities dedicated to the arts, culture and heritage also implies, to teachers' opinions, contributions such as: teaching the pupil how to be a good arts receiver and maker; sensitising them from an early age to the aesthetical and cultural component in the context of heritage; cultivating their taste for the beautiful; helping them develop in an harmonious way.

The usefulness of arts and cultural activities for fostering communication, connection and team work is acknowledged by both pupils and parents. For the latter, children's communication ability is a strength not only in relation to school activity, but also to the competences they need out of school and throughout their life. For parents, communication and collaboration are aspects which associate with personal and socio-professional success. 
With regard to the development of intellectual abilities, we can see that all the participants in this study give importance to creativity. Average in frequency, there are mentions of benefits concerned with critical thinking, through observation, discovery, analysis, reflection. The references to problem solving skills or self-assessment skills are rarer (although they are formulated as aims in all curriculum of Romanian school education). The exploitation of the potential for pupils' development through arts, culture and heritage activities is influenced by the fact that teachers organise these activities punctually, in a relatively discontinuous way. The small number of opinions expressed by teachers with regard to the ability to implement a full cycle of activities let us know that such abilities could be still missing and there would be some training needs to that effect. They admit that their ability to develop full cycles of activities is strengthened by their work experience gained in the course of some projects conducted at school and by the support of specialists from other partner institutions.

\section{The evaluation of activities and the quality of feedback}

Generally, according to our research data, we can see that all organisers allot only a small part of the total time dedicated to an activity to the evaluation of its outcomes. Practices involving reflection on and evaluation of the quality of the outcomes are not sufficiently used by teachers in their collaboration with pupils or parents. A recent study of assessment and examination in Romania conducted under the OECD aegis reveals that pupil assessment is predominantly focused on examination, which limits the learning process, and teachers need support in order to apply formative evaluation and collect quality feedback (Unicef, 2017). Cultural operators are aware of the need to evaluate the activities and the programmes they suggest, but they also know there are few evaluation tools at hand. They think that the evaluation component needs to be addressed in a professional way, and the teachers are those qualified to do it. To conclude, the deficiencies related to the evaluation of pupils' activity in the Romanian education system also lead to a waste of the formative resources provided by these types of educational activities, despite the fact that feedback collection practices are more frequent. 
Consultation of pupils and parents by schools has become a more systematic practice due to changes regarding the evaluation and accreditation of schools. It normally includes also topics about the school educational provision for optional subjects and extracurricular activities. As regards the organisation of activities dedicated to the artistic and cultural field, our research data show that parents and teachers collaborated most of the times in order to solve administrative issues related to the necessary resources. Instead, the consultation of parents for providing feedback at the end of an activity was confirmed by only a quarter of the respondents $(24.2 \%)$. The analysis of their own engagement during the most recent artistic and cultural activities organised by teachers, for the purpose of assessing the outcomes or for communicating their degree of satisfaction, was mentioned by less than half of the pupils.

The capacity of the school organisation to appreciate the formative role of feedback as a form of learning was a subject of interest in this research, which lead us to try to relate more field data in order to get a better picture of this practice. To that effect, the research of the mechanisms used to apply the curriculum in the classroom reveals that the feedback provided by the school manager, colleagues, pupils, parents is not found among the first half of factors which influence the quality of education (Bercu, 2012, p. 263). There are informal practices and also formal ones (teacher councils) in schools, which allow teachers to analyse the extent to which the objectives of educational activities have been attained. Throughout the "Şcoala altfel" Programme, for example, the beneficiaries are consulted with the help of questionnaires and interviews (45.9\%) or through informal discussion (44.2\%) (Măntălu ă \& Velea, 2013, p. 43). To the opinion of cultural operators and also that of teachers, the criteria for the appraisal of arts and cultural activities are such as the participants' degree of engagement and reaction to tasks, as well as the participants' impressions at the end of the activities and the pupils' desire to repeat or to extend an experience (with other activities or the provision of optional curricula). For cultural operators, the impact of an activity is considered positive if the formal relation established with the school and the participants continues after the end of a particular project. Therefore, they want to establish a communication channel which helps, in bureaucratic terms, to connect with the pupils. 


\section{Conclusions}

In the course of this article, we have intended to outline an overview of the practices connected with educational activities dedicated to the arts, culture and heritage in the Romanian education system, taking into consideration the available research data and the legislative and administrative changes which have occurred in schools since 2009 up to the present. The introduction of a new national curriculum in Romania, developed in a key competence perspective, keeps the arts subjects as compulsory provision and ensures equal access to this type of education for all children. Education for the arts, culture and heritage still can be accessed and developed through the mechanism of compulsory subjects which is available to all schools and applicable dependant on children's concrete needs and interests. Since 2011, the national programme "Şcoala altfel" ("A Different Kind of School") has been in place, which provides a more flexible administrative context for developing educational activities during school time and with the participation of all children. The programme generated an increase in the number of activities dedicated to the arts, culture and heritage. However, at present, there is no national programme with a specific object to foster the arts and culture in education.

At local level, schools have gained more experience due to development strategies for extracurricular activities school based curriculum and partnerships with the community proposed in order to be in line with the management mechanisms of the quality of education. Over the considered period, there was a significant increase in the provision of arts and culture activities open to all children. Such activities were mainly facilitated by teachers and most frequently they took place at school. At the same time, we could also see an increase with regard to practices of collaboration with parents and representatives of cultural institutions or organisations, which helped teachers in their endeavour to solve the issues related to lack of resources (human, material, and space and time resources). The experiences offered by the school were concerned, most of the times, with fields such as music, dance, theatre, literature, film, and painting. There is openness to new fields such as photography, crafts and handicrafts, computer graphics, architecture and urbanism, but this kind of experiences occupies only a modest part of the entire provision. Educational activities and programmes dedicated 
to cultural heritage are still timorous in finding a place in school practice, given the fact that the interest in heritage continues to be almost absent in public speech too and also in the responsible attitudes of everyday life in Romanian society. The issues related to how the arts activities should respond to the development of new technology, new media and the recommendation for more cross-curricular work are still in search of solutions, not only in this area but also with regard to the whole of the education system. The offers targeted at activities dedicated to "creative industries" or focused on voluntary participation continue to take small steps towards finding their place in the area of school interest.

The limited time teachers dedicate to evaluation reveals difficulties which are due to the fact that, in the Romanian education system, formative evaluation has not gained much ground in classroom practice since 2009 compared to summative evaluation. The emphasis put on the importance of the results at examinations at the expense of learning leaves a mark on teachers' actions at all school subjects, not only in the case of arts and cultural activities which take place with school involvement. This also influence the quality of feedback, where the collection of feedback through the consultation of pupils and parents points to institutional obligations and does not seem to be better used as a learning benefit. An observation of the correlations existing between different sequences of evaluation (from classroom activities to extracurricular artistic and cultural activities) might shape new subjects of interest for research in order to identify to what extent evaluation is, in fact, a criterion of the quality of education which is relevant to the school organisation. This will help also to develop an appropriate teacher training provision in order to increase the role of arts, culture and heritage educational activities in enhancing school attractiveness and the learning benefits.

\section{Note}

1. http://culturaineducatie.ro/proiecte-2/lectiile-patrimoniului/; http://culturaineducatie.ro/wp-content/uploads/2016/03/Nevoi-\%E2\%80\%93final.pdf; http://www.globalmindscape.ro/; http://edupatrimoniu.piscu.ro/. 


\section{References}

- Bamford, A., \& Wimmer, M. (2012). The Role of Arts Education in Enhancing School Attractiveness: a literature review. EENC Paper. Retrieved from http:// www.interarts.net/descargas/interarts2548.pdf.

- Bercu, N. (coord.). (2012). Mecanisme şi practici de aplicare şi de dezvoltare a curriculumului la nivel de şcoală şi de clasă. Bucharest: Institute of Educational Sciences (Institutul de Ştiin e ale Educa iei). Unpublished document, available in the library if the Institute of Educational Sciences.

- Council of Europe. (2005). Council of Europe Framework Convention on the Value of Cultural Heritage for Society. Retrieved from http://conventions.coe.int/ Treaty/Commun/QueVoulezVous.asp?NT $=199 \& \mathrm{CM}=8 \& \mathrm{CL}=\mathrm{FRE}$.

- Council of Europe. (2009). Recommendation 1884 (2009) Cultural education: the promotion of culture, creativity and intercultural understanding through education. Retrieved from http://assembly.coe.int/nw/xml/XRef/XrefXML2HTML-en.asp?fileid=17773\&lang=en.

- EACEA. (2009). Education artistique et culturelle à l'école en Europe. Bruxelles: Eurydice. Retrieved from http://eacea.ec.europa.eu/Education/eurydice/ documents/thematic_reports/113FR.pdf.

- European Parliament. (2006). Recommendation of the European Parliament and of the Council on key competences for lifelong learning (2006). 18 Dec. 2006, 2006/962/EC. Retrieved from http://eur lex.europa.eu/LexUriServ/LexUri Serv.do?uri=OJ:L:2006:394:0010:0018:EN:PDF.

- Iacob, M., \& Mihăilescu, A. (coord). (2016). Arta în şcoală: concepte şi practici. Bucharest: Ed. Universitară. Retrieved from http://www.editurauniversitara.ro/ carte/pedagogie-95/arta_in_scoala_concepte_si_practici/11465.

- Lauret, J.-M., \& Marie, F. (coord). (2010). Final report. Working Group on developing synergies with education, especially arts education.

Retrieved from http://kultura.kreativeuropa.hu/letolt/KrEu/OMC/Synergies_ between_culture_and_education_FULL.pdf.

- Legea Educa iei Na ionale nr.1/2011. http://www.edu.ro/index.php/legaldocs/ 14847.

- Măntălu ă, O., \& Velea, S. (coord). (2013). ,SScoala altfel”: să ştii mai multe să fii mai bun! Evaluarea programului na ional de activită $i$ extracurriculare şi extrasscolare 2012 2013. Bucharest: Institutul de Ştiin e ale Educa iei. Retrieved from http://www.ise.ro/wp content/uploads/2014/06/Evaluare_Scoala_Altfel.pdf.

- National Advisory Committee on Creative and Cultural Education (NACCCE). (1999). All Our Futures: Creativity, Culture and Education. London: Department for Education and Employment. Retrieved from http://files.eric.ed.gov/fulltext/ ED440037.pdf. 
- UNESCO. (2006). Road Map for Arts education. Retrieved from http://www.unesco.org/new/en/culture/themes/creativity/ arts education/official texts/road map/.

- UNESCO. (2010). Seoul Agenda. Goals for the development of Arts education. Retrieved from http://www.unesco.org/new/en/culture/themes/ creativity/arts education/official texts/development goals/.

- UNICEF. (2017). Studii OCDE privind evaluarea şi examinarea. România. Retrieved from http://www.unicef.ro/publicatii/studiile-ocde-privind-evaluareasi-examinarea-in-domeniul-educatiei/.

- Winner, E., Goldstein, T. R., \& Vincent Lancrin, S. (2013). Art for art's sake? The impact of arts education. Overvew. OECD Publishing. Retrieved from https://www.oecd.org/edu/ceri/ART\%20FOR\%20ART\%E2\%80\%99S\%20SA KE\%20OVERVIEW_EN_R3.pdf.https://doi.org/10.1787/9789264180789-en.

The online version of this article can be found at: http://revped.ise.ro/category/2018-en/

\section{$( c c ) \longdiv { B V - N O - S A }$}

This work is licensed under the Creative Commons Attribution-NonCommercial-ShareAlike 4.0 International License.

To view a copy of this license, visithttp://creativecommons.org/licenses/by-ncsa/4.0/ or send a letter to Creative Commons, $P O$ Box 1866, Mountain View, CA 94042, USA.
Versiunea online a acestui articol poate fi găsită la:http://revped.ise.ro/category/2018-ro/

\section{(cc) DY-Ne-za}

Această lucrare este licen iată sub Creative Commons Attribution-NonCommercial-ShareAlike 4.0 International License.

Pentru a vedea o copie a acestei licen e, vizita $i$ http://creativecommons.org/licenses/by-nc-sa/4.0/ sau trimite i o scrisoare către Creative Commons, PO Box 1866, Mountain View, CA 94042, SUA. 